\title{
Temperature sensitivity of resistance to two pathotypes of Plasmodiophora brassicae in Brassica oleracea
}

\author{
R. L. GABRIELSGN and JÓZEF ROBAK
}

Western Washington Research and Extension Center, Puyallup, WA 98371 USA

Research Institute of Vegetable Crops, 96-100 Skierniewice, Poland

(Received: March 16, 1987)

\begin{abstract}
Several methods were evaluated in an attempt to develop a greenhouse screening procedure that would predict field resistance of brassica breeding lines to clubroot disease caused by Plasmodiophora brassicae. Several Brassica oleracea cultivars and breeding lines bred for resistance to Plasmodiophora brassicae and a susceptible Chinese cabbage cultivar were exposed to high levels of inoculum of both pathotypes PB 6, PB 7 at $12,15,20,25$ and $30^{\circ} \mathrm{C}$. No infection occurred on any host at $12^{\circ} \mathrm{C}$. Chinese cabbage was heavily diseased from $15-30^{\circ} \mathrm{C}$. Bagder Shipper cabbage, a cauliflower deriving resistance from this variety, and Oregon CR-1 broccoli were resistant to pathotype PB 6 at 15 and $20^{\circ} \mathrm{C}$ and partially resistant at 25 and $30^{\circ} \mathrm{C}$. They were resistant to pathotype $\mathrm{PB} 7$ and $15^{\circ} \mathrm{C}$ and almost totally susceptible at $20,25^{\circ}$ and $30^{\circ} \mathrm{C}$. Oregon cabbage line $O R 123$ was resistant to pathotype $\mathrm{PB} 6$ at $15^{\circ} \mathrm{C}$ at almost completely susceptible at 20,25 and $30^{\circ} \mathrm{C}$. It was resistant to pathotype PB 7 at all temperatures. Temperature sensitivity of resistance can partially explain why breeding lines are resistant in field trials and susceptible in greenhouse tests.
\end{abstract}

\section{INTRODUCTION}

Broccoli and cauliflower are well suited to production in the Pacific Northwest (USA). However, clubroot disease is a major constraint in all major production areas. Breeding programs to develop cole crops resistant to Plasmodiophora brassicae Wor. have been in progress in Washington $(\mathrm{Gab}$ rielson, 1977) and Oregon (Baggett, 1976, 1983) for many years.

Even though clubroot resistance in Brassica oleracea is reported to be controlled by recessive genes (Crute et al., 1980), some of the progeny of selfgin resistant plants become severely clubbed in the field. Many of the clubs formed on these plants were large, typical of those formed on susceptible cultivars (Williams, 1966). It was unknown whether this reflected complex 
inheritance of clubroot resistance in our breeding lines or the effects of inoculum potential or environment. It has been reported in Europe that resistance in $B$. oleracea is incomplete under conditions of high inoculum potential ( $\mathrm{Crute}$ et al., 1980).

Temperature is known to affect resistance to disease (Loegering and Harmon, 1981). Until these questions were answered, our breeding program could not proceed. We further face the anomaly of Bagder Shipper derived resistance to be susceptible, to pathotype PB 7 following greenhouse inoculation (Williams, 1966) being successfully used in field breeding programs (Gabrielson, 1977; Rick and Parkins, 1955) to control clubroot in areas where pathotype PB 7 is predominant.

In an attempt to develop a greenhouse screening procedure which would predict field performance, several parameters were investigated. Reported herein are the results of tests exposing resistant and susceptible brassicas to pathotypes PB 6 and PB 7 at different temperatures. A preiminary report of this work has been published (Robak and Gabrielson, 1983).

\section{MATERIALS AND METHODS}

Temperature control experiments were performed in growth chambers (Percival model MB-60 B Boone IA 50036). Temperatures were adjusted to maintain soil temperatures of $12,15,20,25$ and $30^{\circ} \mathrm{C} \pm 1^{\circ} \mathrm{C}$. A light period of $14 \mathrm{~h}$ with cool white fluorescent + incandescent at about 8000 lux, was provided every $24 \mathrm{~h}$.

The following brassicas were tested: Chinese cabbage var. Michihli (susceptible to all pathotypes, B aggett, 1976) cabbage var. Badger Shipper (resistant to pathotype PB 6, susceptible to pathotype PB 7) (Williams, 1966; Buczacki, et al. 1975), broccoli var. Oregon CR-1 (resistant to pathotype PB 6, field resistant in the Pacific Northwest) (B a g e t t, 1976), WA-WI cauliflower (clubroot resistance from Badger Shipper) (Paul Williams, personal communication) and selected for field resistance in Western Washington), Oregon cabbage breeding line OR 123 (selected for resistance to clubroot in Corvallis, OR) (Baggett, 1983). The predominant pathotype in the midwestern United States is pathotype PB 6 (Williams and Walker, 1963). The predominant pathotype on the West Coast is pathotype PB 7 (Dobson et al., 1983; Williams and Walker, 1963).

Pathotype PB 6, supplied by Paul Williams, was maintained and increased by both Brassica juncea and Chinese cabbage, in separate greenhouses. Pathotype PB 7 was collected from infected Chinese cabbage in field trials reported in this paper. The susceptibility of Oregon breeding line OR 123 to pathotype PB 6 and its resistance to pathotype PB 7 in the greenhouse is 
evidence this source was not contaminated with pathotype PB 6. Resting spore suspensions of each pathotype were obtained by macerating fresh clubs in water and straining the macerate through four layers of cheesecloth. Spore suspensions were adjusted to $10^{7}$ spores per $\mathrm{ml}$, stored in a refrigerator at about $4^{\circ} \mathrm{C}$ and used within one week.

Seeds were germinated for 6 days on moist filter paper on slanted Petri dishes. Plastic pots $(7 \times 7 \times 7 \mathrm{~cm})$ filled with moistened Peat litte mix $\mathrm{R}$ (Cornell) (W. R., Grace and Co., Cambridge, MA 02140) with a $\mathrm{CaCl}_{2} \mathrm{pH}$ of 5.2 were placed in plastic trays without drainage holes. Trays were covered with aluminium foil to reduce radiant heating of soil. Four holes were punched through the aluminium foil into each pot. One $\mathrm{ml}$ of spore suspension was pipetted into each hole. One seedling was then transplanted into each hole. There were 24 test plants in 6 pots planted for most experimental variables in each experiment. Pathotypes were kept in separate trays. Plants were kept from drying out by watering in trays. Disease incidence was recorded after 7 weeks. All plants with definite clubs were recorded as infected. Data reported are combined from 2 experiments.

In field trials, brassica lines were direct seeded each year in Sultan silt loam, fine-silty, mixed nonacid, mesic aquic xerofluvent, $\mathrm{CaCl}_{2} \mathrm{pH} 5.2$, naturally infested with $P$. brassicae. Each variety or line was paired with Chinese cabbage. There were two replications of each variety or line each year. After planting, the soil was throughly wet by rain (1982) or irrigation (1981) to favor club root infection. Clubroot symptoms were recorded on plants at maturity.

\section{RESULTS}

No clubs developed on any host, including Chinese cabbage at $12^{\circ} \mathrm{C}$. At $15^{\circ} \mathrm{C}$ and above moderate to heavy clubbing occurred in Chinese cabbage (Table 1) with both pathotypes PB 6 and PB 7. Reaction of the resistant lines to the two pathotypes at different temperatures is detailed in Tables 1 and 2.

Badger Shipper cabbage, WA-WI cauliflower and Oregon CR-1 broccoli were resistant to pathotype $\mathrm{PB} 6$ at 15 and $20^{\circ} \mathrm{C}$ and partially resistant at 25 and $30^{\circ} \mathrm{C}$. They were resistant to pathotype $\mathrm{PB} 7$ at $15^{\circ} \mathrm{C}$, and almost totally susceptible at 20,25 and $30^{\circ} \mathrm{C}$. Oregon cabbage breeding line $\mathrm{OR} 123$ was resistant to pathotype $\mathrm{PB} 6$ and $15^{\circ} \mathrm{C}$ and almost completely susceptible at 20 , 25 and $30^{\circ} \mathrm{C}$. It was resistant to pathotype PB 7 at all temperatures.

In field trials, Badger Shipper, WA-WI cauliflower, and Oregon CR-1 broccoli were resistant in 1981, but not in 1982, while cabbage Oregon breeding line OR 123 resistance was complete both years. Chinese cabbage, paired with each variety and line was uniformly infected both years (with rare scattered escapes). 
Table 1

Percentage of plants with clubroot disease in resistant and susceptible brassicas exposed to two pathotypes of Plasmodiophora hrassicae in growth chambers at different temperature ${ }^{1}$

\begin{tabular}{|c|c|c|c|c|c|c|c|c|}
\hline \multirow{2}{*}{ Temperature $^{2}$} & \multicolumn{4}{|c|}{ Pathotype PB 6} & \multicolumn{4}{|c|}{ Pathotype PB 7} \\
\hline & $15^{\circ} \mathrm{C}$ & $20^{\circ} \mathrm{C}$ & $25^{\circ} \mathrm{C}$ & $30^{\circ} \mathrm{C}$ & $15^{\circ} \mathrm{C}$ & $20^{\circ} \mathrm{C}$ & $25^{\circ} \mathrm{C}$ & $30^{\circ} \mathrm{C}$ \\
\hline Chinese cabbage & $75^{\mathrm{ijk}}$ & $100^{\mathrm{q}}$ & $100^{q}$ & $96^{\text {op }}$ & $68^{\mathrm{hi}}$ & $80^{j \mathbf{k} / \mathrm{m}}$ & $100^{4}$ & $99^{\mathrm{q}}$ \\
\hline Bagder Shipper & $0^{\mathbf{a}}$ & $0^{\mathbf{a}}$ & $23^{\mathrm{de}}$ & $36^{\mathrm{fg}}$ & $0^{\mathrm{a}}$ & $31^{\mathrm{ef}}$ & $65^{\text {h }}$ & $86^{1 \mathrm{~m}}$ \\
\hline WA-WI cauliflower & $0^{\mathrm{a}}$ & $0^{\mathrm{a}}$ & $17^{\mathrm{cd}}$ & $44^{\mathrm{g}}$ & $0^{a}$ & $87^{\mathrm{mn}}$ & $79^{\mathbf{j k l m}}$ & $90^{\text {no }}$ \\
\hline Oregon CR-1 broccoli & $8^{\mathrm{b}}$ & $9^{\mathrm{bc}}$ & $30^{\text {ef }}$ & $29^{\mathrm{ef}}$ & $0^{\mathrm{a}}$ & $74^{\mathrm{ij}}$ & $79^{\mathrm{jk} \operatorname{lm}}$ & $84^{\mathrm{klm}}$ \\
\hline Oregon cabbage line & & & & & & & & \\
\hline OR-123 & $7^{b}$ & $79^{\mathbf{j k} / \mathrm{m}}$ & $93^{\text {op }}$ & $73^{\mathrm{hij}}$ & $0^{\mathrm{a}}$ & $0^{\mathrm{a}}$ & $0^{\mathbf{a}}$ & $8^{b}$ \\
\hline
\end{tabular}

Values in each column not followed by the same letter differ significantly by the Student Multiple Range Test at $P=0.05$.

${ }^{1}$ Plants grown in Peat-Lite mix R. Resting spores were harvested from fresh clubs. One $\mathrm{ml} \mathrm{of} 10^{7}$ spores $/ \mathrm{ml}$ resting spore suspension was pipetted into each hole One-weck old seedings were transplanted into each hole

${ }^{2}$ At $12^{\circ} \mathrm{C}$ no clubbing was observed in any host.

3 Data from only one trial. All other growth chamber data combined from two. 
Table 2

Percentage of plants with clubroot disease in resistant and susceptible brassicas exposed to pathotype PB 7 of Plasmodiophora hrassicae in field trials in Western Washington

\begin{tabular}{lcc}
\hline \multirow{1}{*}{ Hosts } & \multicolumn{2}{c}{ Field trials } \\
\cline { 2 - 3 } & 1981 & 1982 \\
\hline Chinese cabbage & 100 & 100 \\
Bagder Shipper & $14^{\mathrm{c}}$ & $96^{\mathrm{e}}$ \\
WA-WI cauliflower & $6^{\mathrm{b}}$ & $95^{\mathrm{e}}$ \\
Oregon CR-1 broccoli & $18^{\mathrm{c}}$ & $53^{\mathrm{d}}$ \\
Oregon cabbage line & & \\
OR-123 & $0^{\mathrm{a}}$ & $0^{\mathrm{a}}$ \\
\hline
\end{tabular}

\section{DISCUSSION}

Loss of resistance to plant disease with increase in temperature is well known (Loegering and Harmon, 1969; Walker and Smith, 1930). These results demonstrate that temperature affects the resistance expressed by these varieties and breeding lines to the two pathotypes.

Oregon CR-1 has been resistant in field trials in the Pacific coast states (B aggett, 1976). WA-WI cauliflower has also been resistant in field trials in Washington and California. Spring planted crops are often planted in soil at or below $15^{\circ} \mathrm{C}$ which could partially account for the field resistance observed. The field trials reported in Table 2, however, were planted in mid-summer. We were unaware of the temperature phenomenon at the time and no records of soil temperatures were kept. Air temperatures both years were high for the month following planting. In 1981 there was no rain during this period. In 1982 there was frequent intermittent rain. The conditions were ideal for clubroot disease in 1982. Resistance in Bagder Shipper and Oregon CR-1 was not expressed down, while it was in Oregon cabbage breeding line OR 123.

As Oregon cabbage breeding line OR 123 is susceptible to pathotype PB 6, it is obvious that $P$. brassicae pathotype in the field trial was pathotype PB 7 only. The susceptibility of Oregon cabbage breeding line OR 123 to pathotype PB 6 offers a means of differentiating pathotype PB 6 in the presence of pathotype $\mathrm{PB} 7$, and this line should be a valuable addition to the European Clubroot Differential (ECD) set (Buczacki et al., 1975).

Although the work of Dobson et al. (1983) showed pathotype PB 7 to be the only pathotype present in the Pacific coast states, there was at that time no practical means of differentiating pathotype PB 6 in the presence of pathotype PB 7. There should therefore, be extensive resampling of infested areas with Oregon cabbage breeding line OR 123 before longterm breeding programs are undertaken with this germ plasm. It would be good to combine both Badger 
Shipper or Oregon cabbage breeding line OR 123 resistance, giving a high level of resistance to both pathotypes. A plant breeder using conventional breeding techniques should be able to accomplish this in about 20-30 years.

Temperature control with growth chambers is not economically feasible for plant breeders and pathologists in most private companies. In trials not reported here we were able to achieve the same differentiation reported in Table 1 in greenhouse temperature tanks where soil temperature was maintained at $21^{\circ} \mathrm{C}$. Until now it has not been practically possible to indentify pathotype PB 6 in a mixture of pathotype PB 6 and PB 7. Thus OR 123 could be inoculated onto Bagder Shipper to determine if they are pathotype PB 6 .

\section{REFERENCES}

Baggètt J. R., 1976. Oregon CR-1 Broccoli. Hort. Sci. 11: 622-623.

Baggett J. R., 1983. Clubroot resistant cabbage breeding lines Oregon 100, 123, 140 and 142. Hort. Sci. 18: $112-114$.

Buczacki S. T., Toxopeus H., Matusch P., Johnston T. D., Dixon G. R., Hobolth L. A., 1975. Study of physiological specialization through an international approach. Trans. Br. Mycol. Soc. 65: 295-303.

Crute I. R., Gray A. R., Grisp P., Buczacki S. T., 1980. Variation in Plasmodiophora brassicae and resistance to clubroot disease in Brassicas and allied crops - a critical review. Plant Breeding Abstr. 50: 91-104.

Dobson R. L., Robak J., Gabrielson R. L., 1983. Pathotypes of Plasmodiophora brassicae in Washington, Oregon, and California, USA Plant Disease. Plant Disease 67: 269-271.

Gabrielson R. L., 1977. Breeding for resistance to clubroot in broccoli (calabrese) and cauliflower in western Washington. Proc. Woronin + 100 Conf., Univ of Wisconsin, Madison, $121 \mathrm{pp}$.

Loegering W. Q., Harmon D. L., 1969. Wheat lines near-isogenic for reaction to Puccinia graminis tritici. Phytopathology 56: 624-626.

Rick C. M., Perkins D. Y., 1955. Resistance to clubroot disease is goal of breeding project in Brussels sprouts. Calif. Agr. 9 (4): 8-11.

Robak J.; Gabrielson R. L., 1983. Temperature sensitivity of resistance to two pathotypes of Plasmodiophora brassicae in Brassica oleracea p. 192 in Fourth International Congress of Plant Pathology, Abstract of Papers, Rowprint Services, Victoria, Australia.

Walker J. C., Smith R., 1930. Effect of environmental factors upon the resistance of cabbage to yellows. J. Agr. Res. 41: 1-15.

Williams P. H., 1966. A system for the determination of races of Plasmodiophora brassicae that infect cabbage and rutabaga. Phytopathology 56: 624-626.

Williams P. H., Walker J. C., 1963. Races of clubroot in North America. Plant Disease Rep. 47: $608-611$. 


\section{Wplyw temperatury na odporność roślin kapustnych na dwa patotypy kiły kapusty (Plasmodiophora brassica')}

\section{Streszczenie}

W warunkach szklarniowych badano wpływ temperatury podłoża na odporność na kiłę kapusty kilku linii hodowlanych i odmian kapusty i kalafiorów używanych jako źródła odporności do hodowli odmian odpornych na kiłę kapusty. Użyto dwóch patotypów grzyba Plasmodiophora brassicae; PB 6 i PB 7 przy temperaturach podłoża: $15,20,25$ i $30^{\circ} \mathrm{C}$.

Roślina kontrolna - kapusta chińska - wykazala całkowitą wrażliwość na obydwa patotypy we wszystkich badanych temperaturach. Kapusta Bagder Shipper oraz linie hodowlane kalafiorów WA i WI oraz brokuła OR CR-1 wykazały odpornośc na patotyp PB $6 \mathrm{w}$ temperaturze 15 i 20 C, podczas gdy w temperaturze 25 i $30^{\circ} \mathrm{C}$ mialy tylko odporność cześciową.

Wszystkie badane odmiany wykazały odporność na patotyp PB $7 \mathrm{w}$ temperaturze $15^{\circ} \mathrm{C}$, natomiast $w$ temperaturach wyższych były całkowicie wrażliwe. Linia hodowlana OR 123 wykazała pelną odporność na patotyp PB 6 w temperaturze $15^{\circ} \mathrm{C}$, natomiast w temperaturach: 20,25 i $30^{\circ} \mathrm{C}$ okazala się całkowicie wrażliwa. Stwierdzono natomiast całkowitą odporność linii OR123 na patotyp PB 7 we wszystkich badanych temperaturach podłoża.

Wysunięto hipotezę, że mechanizm zmiennej odporności testowanych linii hodowlanych i odmian roślin kapustnych na kiłę oprócz uwarunkowań genetycznych uzależniony jest od temperatury podłoża, która wywiera wpływ zarówno na aktywność biologiczną patogena w glebie, jak i na wrażliwość rośliny żywicielskiej.

$\mathrm{Na}$ tej podstawie można częściowo wyjaśnić zjawisko zróżnicowanej odporności badanych roślin wykazujących wyższą odporność w testach polowych i niższą w testach szklarniowych. 